\section{Secretariat for Central American Economic Integration (SIECA)}

SIECA (Secretaría de Integración Económica Centroamericana) was created by the General Treaty of Central American Economic Integration in Dec. 1960. The General Treaty incorporates the Agreement on the Regime for Central American Integration Industries. In Oct. 1993 the Protocol to the General Treaty on Central Economic Integration, known as the Guatemala Protocol, was signed.

Members. Costa Rica, El Salvador, Guatemala, Honduras, Nicaragua. Observer: Panama.

Official language: Spanish.

Headquarters: 4a Avenida 10-25, Zona 14, Ciudad de

Guatemala, Guatemala.

Website: http://www.sieca.org.gt

Secretary-General: Haroldo Rodas Melgar (Guatemala).

\section{South American Community of Nations (CSN/SACN)}

In Dec. 2004 representatives of 12 South American countries signed the 'Cuzco Declaration' thereby founding a political and economic bloc modelled on the European Union. The aim is to establish a single currency, passport and parliament. The South American Community of Nations (SACN) will be created by the merger of the two existing major South American trade blocs: the Andean Community (Bolivia, Colombia, Ecuador, Peru and Venezuela) and the Southern Common Market or MERCOSUR (Argentina, Brazil, Paraguay and Uruguay), in addition to the market of Chile, and eventually those of Suriname and Guyana. The agreement paves the way for much-needed improvements in transport, energy and other infrastructure, thus facilitating intra-continental trade. The SACN aims to eliminate tariffs on non-sensitive products by 2014 and those on sensitive products by 2019 . The bloc will create a single market of $361 \mathrm{~m}$. people with a combined GDP of US\$973bn. However, insufficiently defined goals and ongoing disputes between members of the alreadyexisting blocs may hamper development, as may future bilateral trade negotiations with the USA.

\section{Southern Common Market (MERCOSUR)}

Founded in March 1991 by the Treaty of Asunción between Argentina, Brazil, Paraguay and Uruguay, MERCOSUR committed the signatories to the progressive reduction of tariffs culminating in the formation of a common market on 1 Jan. 1995. This duly came into effect as a free trade zone affecting $90 \%$ of commodities. A common external tariff averaging $14 \%$ applies to $80 \%$ of trade with countries outside MERCOSUR. Details were agreed at foreign minister level by the Protocol of Ouro Preto signed on 17 Dec. 1994.

In 1996 Chile negotiated a free-trade agreement with MERCOSUR which came into effect on 1 Oct. Subsequently Bolivia, Colombia, Ecuador and Peru have all been granted associate member status.

Organization. The member states' foreign ministers form a Council responsible for leading the integration process, the chairmanship of which rotates every six months. The permanent executive body is the Common Market Group of member states, which takes decisions by consensus. There is a Trade Commission and Joint Parliamentary Commission, an arbitration tribunal whose decisions are binding on member countries, and a secretariat in Montevideo.

Further to the treaty signed by 12 South American countries in Dec. 2004, MERCOSUR will gradually be integrated into the new South American Community of Nations.

Headquarters: Rincón 575 P12, 11000 Montevideo, Uruguay. Website: http://www.mercosur.org.uy (Spanish and Portuguese only)

Administrative Secretary: Reginaldo Braga Arcuri (Brazil).

\section{Asian Development Bank}

A multilateral development finance institution established in 1966 to promote economic and social progress in the Asian and Pacific region, the Bank's strategic objectives in the medium term are to foster economic growth, reduce poverty, improve the status of women, support human development (including population planning) and protect the environment.

The bank's capital stock is owned by 64 member countries, 46 regional and 18 non-regional. The bank makes loans and equity investments, and provides technical assistance grants for the preparation and execution of development projects and programmes; promotes investment of public and private capital for development purposes; and assists in co-ordinating development policies and plans in its developing member countries (DMCs).

The bank gives special attention to the needs of smaller or less developed countries, giving priority to regional, sub-regional and national projects which contribute to the economic growth of the region and promote regional co-operation. Loans from ordinary capital resources on non-concessional terms account for about $80 \%$ of cumulative lending. Loans from the bank's principal special fund, the Asian Development Fund, are made on highly concessional terms almost exclusively to the poorest borrowing countries.

Regional members. Afghanistan, Armenia, Australia, Azerbaijan, Bangladesh, Bhutan, Cambodia, China, Cook Islands, East Timor, Fiji Islands, Hong Kong, India, Indonesia, Japan, Kazakhstan, Kiribati, South Korea, Kyrgyzstan, Laos, Malaysia, Maldives, Marshall Islands, Micronesia, Mongolia, Myanmar, Nauru, Nepal, New Zealand, Pakistan, Palau, Papua New Guinea, Philippines, Samoa, Singapore, Solomon Islands, Sri Lanka, Taiwan, Tajikistan, Thailand, Tonga, Turkmenistan, Tuvalu, Uzbekistan, Vanuatu and Vietnam.

Non-regional members. Austria, Belgium, Canada, Denmark, Finland, France, Germany, Italy, Luxembourg, Netherlands, Norway, Portugal, Spain, Sweden, Switzerland, Turkey, UK, USA.

Organization. The bank's highest policy-making body is its Board of Governors, which meets annually. Its executive body is the 12member Board of Directors (each with an alternate), eight from the regional members and four non-regional.

The ADB also has resident missions: in Bangladesh; Cambodia; China; India; Indonesia; Kazakhstan; Kyrgyzstan; Laos; Nepal; Pakistan; the Philippines; Sri Lanka; Uzbekistan; Vietnam; and a regional mission in Port Vila, Vanuatu. There are also three representative offices: in Tokyo, Frankfurt and Washington, D.C.

Official language: English.

Headquarters: 6 ADB Avenue, Mandaluyong, Metro Manila, Philippines. 